\title{
KONSEP DESAIN EKOLOGIS RUANG TERBUKA HIJAU DI SUDIRMAN CENTRAL BUSINESS DISTRICT (SCBD) SEBAGAI HABITAT BURUNG
}

\author{
Ecological Design Concept of SCBD's Green Open Space as Bird \\ Habitats
}

\section{Andi Gunawan ${ }^{1}$ dan Setia Permana ${ }^{1}$}

Diterima: 27 November 2017 Disetujui: 6 Juni 2017

\begin{abstract}
Abstrak: Laskap pada kawasan Central Business District (CBD) dapat menjadi bagian dari ruang terbuka hijau (RTH) yang berperan meningkatkan nilai ekologis kota, salah satunya Sudirman Central Business Disctrict (SCBD). Keberadaan burung dapat meningkatkan fungsi ekologi perkotaan. Sehingga perlu memberdayakan fungsi ruang terbuka sebagai habitat burung untuk menciptakan keseimbangan ekologis kota. Tujuan penelitian ini adalah mendesain ruang terbuka hijau sebagai habitat burung. Ruang terbuka hijau Lot 17 SCBD berpotensi untuk dikembangkan sebagai area perlindungan penampungan burung. Area perlindungan terbagi menjadi dua ruang yaitu area bersarang dan transisi. Metode yang digunakan adalah metode deskriptif melalui survei lapang dan studi pustaka. Konsep dasar yang digunakan adalah eco-friendly bird park, yakni taman yang mampu menghadirkan interaksi secara langsung ataupun tidak langsung antara manusia dan burung tanpa mengurangi pemenuhan fungsi ekologi taman tersebut. Konsep desain mengaplikasikan aliran seni deco yang memiliki kesan dinamis dan bentuk plastis yang lentur. Kesan dinamis tersebut akan diterapkan dalam bentuk lengkungan pada pola-pola taman dan sirkulasi dengan bentukan yang irregular sehingga memberi kesan alami. Keberadaan Lot 17 SCBD dapat melunakkan kondisi sekitarnya yang mayoritas adalah gedung bertingkat. Pengunjung dapat mengamati burung yang berada pada kanopi pohon dengan menggunakan fasilitas teropong binokuler yang diletakkan pada deck view dan canopy tree rail.
\end{abstract}

Kata kunci: area penampungan, area perlindungan, daya tarik burung, lanskap perkotaan, taman kota.

\begin{abstract}
Landscape in Central Business District (CBD) is part of urban green spaces which have a role to enhance ecological value of the city, one of them is Sudirman Central Business Distict. The existence of birds will strengthen the ecological functions of the city. The aim of this study is to design the green spaces as bird habitat. Lot 17 SCBD has the potential to be developed as a bird sanctuary protection area divided into two areas: nesting and transition area. The method that will be used for this research is descriptive analysis through site survey and literature. The concept that used is eco-friendly bird park, a park that is able to present the directly or indirectly interaction between humans and birds without reducing the fulfillment of ecological functions of the park. The design concept applies the deco art style that has a dynamic impression and a pliable flexible shape. The dynamic impression will be applied in the form of arches on the park patterns and circulations to create natural impression. The existence of Lot 17 park can soften the surrounding condition, which is a storey building. Visitors can observe birds on tree canopies using binoculars that is placed on the deck view and canopy tree rail.
\end{abstract}

Keywords: bird attraction, bird conservation, landscape, sanctuary, protection area, urban park.

\footnotetext{
${ }^{1}$ Departemen Arsitektur Lanskap, Fakultas Pertanian Institut Pertanian Bogor
} 


\section{PENDAHULUAN}

Jakarta sebagai ibu kota negara dan kota metropolitan mengalami kemajuan yang sangat pesat sehingga menjadikannya sebagai kota jasa (service city) untuk memenuhi kebutuhan bisnis. Seiring dengan kemajuan yang dicapai untuk memenuhi kebutuhan bisnis tersebut maka dikembangkan pemusatan kegiatan perdagangan dan jasa pada rencana pembangunan kota yang dikenal dengan sebutan kawasan Central Business District (CBD). Salah satu kawasan CBD di Jakarta yaitu Sudirman Central Business District (SCBD). Berbagai aktivitas perekonomian dan perdagangan dilakukan disini. Lokasi yang strategis membuat aksesnya mudah untuk dijangkau.

Keberadaan laskap pada kawasan CBD dapat menjadi bagian dari ruang terbuka hijau (RTH) yang berperan meningkatkan nilai ekologis kota dalam skala meso. RTH merupakan komponen penting dalam lanskap perkotaan, yakni menyediakan jasa ekologi dan mendukung keanekaragaman hayati (Strohbach et al. 2013). Pentingnya ruang terbuka hijau perkotaan perlu ditekankan dengan struktur alami untuk mempertahankan keragaman ekologi yang tinggi (Sandstorm et al. 2006). Namun tidak semua penghijauan baik untuk keragaman satwa liar. Penghijauan buatan hanya dapat menciptakan atau mendatangkan keseragaman bagi spesies satwa liar di lanskap perkotaan. Manajemen area perkotaan untuk mendukung kehidupan satwa liar membutuhkan perluasan kawasan alami atau semi alami (Chong et al. 2014). Variabel lingkungan yang memberikan kontribusi besar terhadap keberagaman spesies burung di perkotaan adalah area dengan kepadatan pohon-pohon alami dan area jalan tidak beraspal (Reis et al. 2012).

Sebuah lanskap perkotaan memiliki kemampuan yang signifikan sebagai strategi konservasi perkotaan yang efektif, terutama dalam melestarikan habitat satwa liar (Sulaiman et al. 2013). Meningkatkan kesesuaian matriks untuk satwa liar pada lanskap perkotaan dapat meningkatkan keragamannya (Barth et al. 2014). Adanya asosiasi antara kehidupan liar dengan aktivitas manusia di lingkungan ini, selain menciptakan kenyamanan melalui berbagai bentuk atraksi dan sarana pendidikan lingkungan, juga sangat bermanfaat sebagai sarana penyeimbang lingkungan. Salah satu satwa liar yang masih berkeliaran di kota adalah burung. Ada tiga kategori yang menunjukkan fungsi burung (Schwartz 2008) yaitu ekologi, psikologis dan sosial. Setiap jenis burung sebagai fungsi ekologis dapat memberikan jasa baik secara langsung maupun tidak langsung yang bermanfaat bagi lingkungan dan manusia. Kicauan burung yang berterbangan mampu memberikan ketenangan psikologis bagi yang mengamati. Sedangkan untuk fungsi sosial, kelimpahan spesies burung mampu memberikan nilai estetis untuk suatu daerah, pengalaman belajar yang menyenangkan dan membawa penawaran menarik bagi real estate.

Burung merupakan salah satu kelompok terbesar vertebrata yang banyak dikenal, diperkirakan ada sekitar 8.600 jenis yang tersebar di dunia. Kerusakan lingkungan berdampak pada punahnya burung itu, di samping ulah manusia yang melakukan perburuan unggas tersebut (Sembiring dalam Antara News 2010). Secara umum diamati adanya nilai variabel gangguan manusia yang lebih rendah di taman. Meskipun taman sangat sering dikunjungi oleh manusia, mereka juga mendukung keberadaan beragam spesies burung. Manusia tidak teratur memberi makan burung, tetapi beberapa spesies (misalnya, merpati dan burung pipit) memanfaatkan sisa makanan manusia (Ramirez et al. 2011).

Keberadaan satwa burung pada kawasan bisnis di perkotaan dapat memperkuat fungsi ekologis kota. Oleh karena itu perlu memberdayakan fungsi ruang terbuka sebagai habitat burung untuk menciptakan keseimbangan ekologis kota. Melestarikan keanekaragaman burung dapat diakomodasi dalam kerangka perencanaan kota (Conole et al. 2011) dengan memvariasikan konfigurasi tata ruang ruang hijau (terutama kedekatan jarak diantara ruang hijau tersebut) (Pellissier et al. 2012). Konvigurasi tata hijau tersebut dapat diciptakan dengan menciptakan taman-taman kota ditambah dengan penanaman pohon di kawasan pusat 
bisnis, sehingga mampu mendukung keanekaragaman hayati yang lebih besar, setidaknya untuk burung di perkotaan (Aida et al. 2016).

Tujuan penelitian ini adalah mendesain ruang terbuka hijau sebagai habitat burung untuk meningkatkan integritas antara kehidupan liar dengan aktivitas kehidupan manusia. Secara khusus penelitian ini bertujuan untuk, (1) mengidentifikasi keberadaan satwa burung di kawasan Sudirman Central Business District (SCBD);(2) menganalisis potensi dan kendala tapak ditinjau dari dari fisik, biofisik, dan keberadaan satwa burung;(3)mendesain secara ekologis ruang terbuka hijau di SCBD sebagai habitat burung.

Penelitian ini berlokasi di Sudirman Central Bussines District (SCBD), Jalan Jenderal Sudirman No. 52-53, Senayan, Kebayoran Baru, Jakarta Selatan, Daerah Khusus Ibukota Jakarta (Gambar 1) selama dua bulan dimulai dari bulan Juli 2017 sampai dengan Agustus 2017.

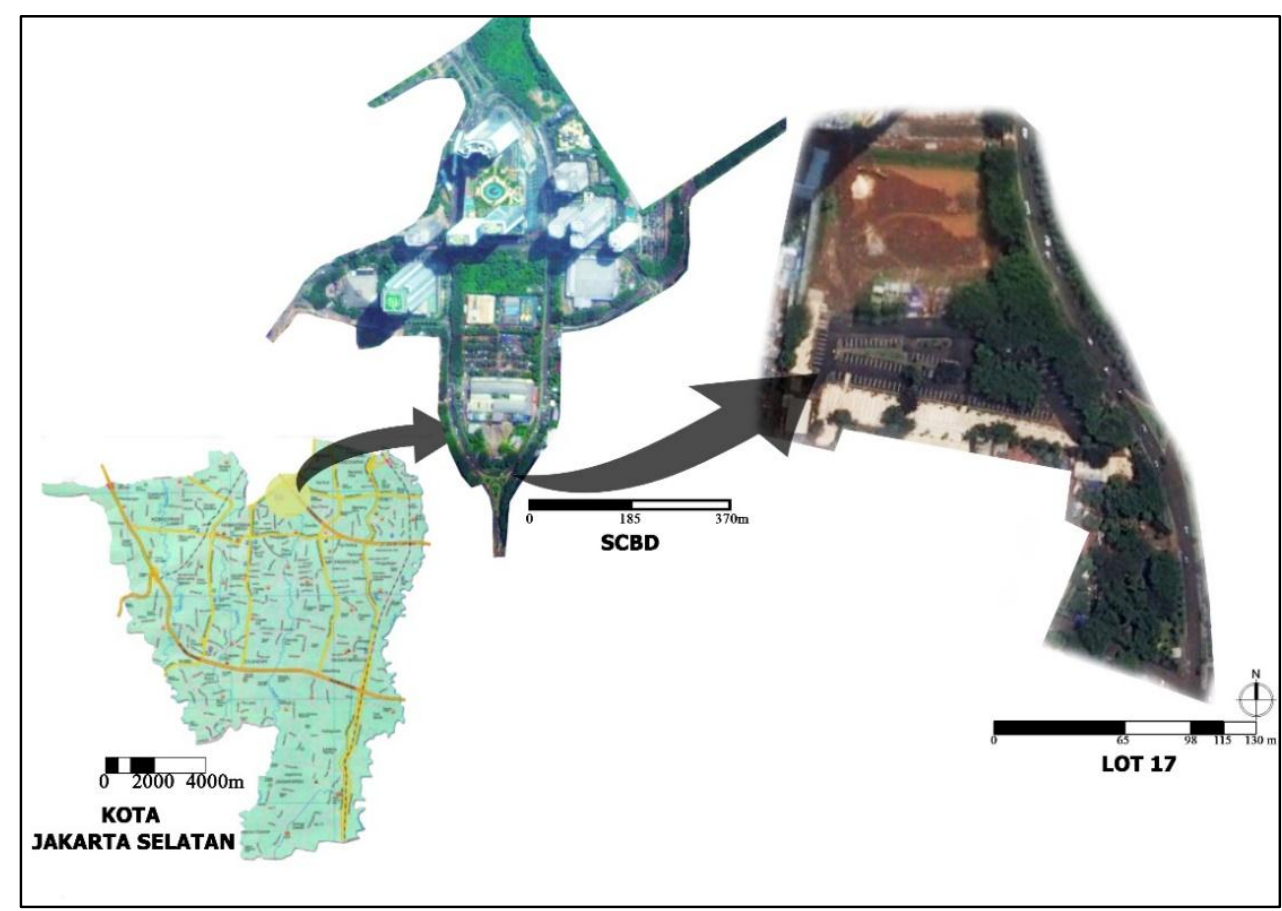

Sumber: google.co.id

Gambar 1. Peta Lokasi Penelitian

\section{METODE PENELITIAN}

Metode yang digunakan adalah metode deskriptif melalui survei lapang dan studi pustaka yang akan dilakukan dalam empat tahapan, yakni tahap persiapan, pengumpulan data, pengolahan data (analisis, sintesis, dan konsep), dan kegiatan desain. Proses penelitian yang akan dilakukan mengacu pada proses desain Booth (1983).

\section{Persiapan}

Pada tahap persiapan dilakukan perumusan masalah dan tujuan dilakukannya penelitian sebagai usulan untuk melakukan desain RTH ekologis di kawasan SCBD. Selanjutnya dilakukan pengumpulan informasi awal terkait lokasi penelitian dan menyusun rencana kegiatan. Selain itu, pengurusan perijinan juga dilakukan dalam tahap ini. 


\section{Pengumpulan Data}

Pada tahap ini akan dilakukan pengumpulan data primer dan data sekunder. Data primer diperoleh melalui pengukuran dan pengamatan secara langsung serta penyebaran kuesioner untuk memperoleh data sosial. Kuesioner ditujukan kepada pengguna tapak dengan jumlah 100 responden yang terbagi menjadi 70 responden pengunjung umum dan 30 responden penduduk setempat. Data sekunder diperoleh melalui lembaga atau instansi terkait dan studi pustaka.

\section{Analisis Sintesis}

Data yang diperoleh selanjutnya akan dianalisis melalui beberapa tahapan, yaitu analisis fisik dan analisis biofisik. Analisis fisik dan biofisik tapak yang dilakukan meliputi sumberdaya tapak, yaitu potensi beserta kendala yang ada pada tapak. Pendekatan desain ekologis (Ecological Design Approach) memiliki perbedaan fundamental dibandingkan pendekatan lainnya (Pratiwi, Gunawan, Fatimah 2014). Hal tersebut menjadi dasar digunakannya konsep ecodesign dalam mengkaji ruang terbuka hijau di perkotaan. Menurut Van der Ryn dan Cowan (1996) terdapat karakteristik tertentu yang menjadi faktor pembeda antara desain konvesional dengan desain berbasis ekologi, adapun faktor-faktor yang perlu diperhatikan dalam tahap analisis sintesis adalah sumber, jenis material, pencemaran zat beracun, akuntansi ekologi, keseimbangan ekologi dan ekonomi, kriteria desain, kepekaan terhadap konteks ekologi, keragaman biologis, budaya dan ekonomi, multidisiplin ilmu, sistem keseluruhan, peranan alam, metafora yang mendasari, tingkat partisipasi, jenis pembelajaran, serta respon terhadap krisis keberlanjutan. Analisis kenyamanan iklim mikro pada periode tertentu selama penelitian dilakukan dengan menggunakan perhitungan THI ( Thermal Humidity Index) serta interview kepada masyarakat sekitar. Dinamika suhu dan kelembaban dapat mempengaruhi kenyaman. Rumus perhitungan THI adalah sebagai berikut (Nieuwolt dan Mc Gregor 1998).

Analisis vegetasi menggunakan data vegetasi yang telah diperoleh sebelumnya, lalu hasilnya diklasifikasikan pada Tabel 1 . Data vegetasi yang telah diperoleh diklasifikasikan berdasarkan (1) nama; (2) jenis; (3) jenis makanan yang dihasilkan; (4) tipe arsitektural; (5) tinggi tanaman; dan (6) jenis burung yang sesuai. Data vegetasi ini diambil berdasarkan sampel jenis RTH pemukiman yang diperoleh. Analisis vegetasi berguna untuk mengetahui lokasi mayoritas burung untuk bersarang, makan, dan mandi serta potensi jenis burung yang dapat dikembangkan.

Tabel 1. Klarifikasi Vegetasi Berdasarkan Kriteria

\begin{tabular}{|l|l|l|l|l|l|}
\hline $\begin{array}{l}\text { Nama } \\
\text { Tanaman }\end{array}$ & $\begin{array}{l}\text { Jenis } \\
\text { tanaman }\end{array}$ & $\begin{array}{l}\text { Jenis makanan } \\
\text { yang dihasilkan }\end{array}$ & $\begin{array}{l}\text { Tipe } \\
\text { arsitektural }\end{array}$ & $\begin{array}{l}\text { Tinggi } \\
\text { tanaman }\end{array}$ & $\begin{array}{l}\text { Jenis burung } \\
\text { yang sesuai }\end{array}$ \\
\hline & & & & & \\
\hline
\end{tabular}

\section{Konsep Desain}

Pada tahap berikut dilakukan pembuatan konsep dasar dan konsep desain lanskap kawasan RTH SCBD dengan basis utama yakni ekologi yang kemudian akan dikembangkan berdasarkan hasil analisis dan sintesis potensi kendala yang telah dikakukan pada tahapan sebelumnya. Pengembangan konsep meliputi konsep ruang, sirkulasi, vegetasi atau tata hijau, hidrologi, serta aktivitas dan fasilitas.

\section{Desain Lanskap}

Pada tahapan ini akan dilakukan proses desain yang diawali dengan pembuatan block plan, yaitu penerjemahan keseluruhan konsep yang telah dibuat dan diintegrasikan dengan kebutuhan ruang sehingga menghasilkan ruang-ruang yang fungsional dalam bentuk gambar 
atau grafis. Hasil block plan ini selanjutnya akan diterjemahkan ke dalam bentuk preliminary design (alternatif gambar desain akhir).

\section{Pengembangan Desain}

Tahap ini merupakan bagian akhir dari suatu proses desain. Pada pengembangan desain akan lebih difokuskan pada pekerjaan desain yang lebih detil hingga penentuan jenis material terutama terkait dengan ilustrasi desain yang akan direalisasikan di lapang.

\section{HASIL DAN PEMBAHASAN}

Tapak yang dijadikan lokasi penelitian berada di Lot 17 (Gambar 12). Luas areanya sebesar $\pm 2,3$ Ha meliputi lahan kosong dengan luas $\pm 3293,6 \mathrm{~m}^{2}$ dan ruang terbuka beserta lahan parkir dengan luas $\pm 2 \mathrm{Ha}$. Tapak yang berupa lahan kosong sedang direncanakan sebagai taman lingkungan, sehingga fasilitas dan utilitas seperti jaringan listrik, drainase, jalur pejalan kaki belum tersedia. Pada area ini terdapat banyak timbunan tanah dan material yang tersebar memenuhi hampir seluruh bagian tapak. Sedangkan tapak yang berupa lahan parkir sudah tersedia jaringan listrik, jalur kendaraan, jalur pejalan kaki, dan drainase. Namun belum tersedia kursi dan fasilitas lainnya yang dapat digunakan oleh pengunjung ketika menggunakan tapak tersebut. Secara geografis lokasi penelitian ini berada pada $6^{\circ} 13^{\prime} 49.6^{\prime \prime} \mathrm{LS}$ dan $106^{\circ} 48^{\prime} 34.05^{\prime \prime} B T$ dengan batas wilayah, PT. Prima Bangun Investama (Lot 10) pada bagian utara, Jalan Tulodong Atas 2 pada bagian timur, Jalan Tulodong dan Tulodong Atas pada bagian selatan, Daerah kavling no. 54 Jalan Jenderal Sudirman pada bagian barat.

\section{Analisis dan Sintesis}

Luas RTH yang dibutuhkan oleh satwa burung untuk bersarang menggunakan teori dari The University of Montana (2010) (Tabel 2).

Tabel 2. Kriteria Luas Habitat Burung Ideal

\begin{tabular}{|c|c|c|c|}
\hline $\begin{array}{l}\text { Area yang } \\
\text { diperlukan }\end{array}$ & Luas area $\left(\right.$ meter $\left.^{2}\right)$ & Keterangan & Kriteria \\
\hline $\begin{array}{l}\text { Area } \\
\text { Perlindungan } \\
\text { (sumber) }\end{array}$ & Lebih dari 50 ha & Untuk daerah bertelur & $\begin{array}{ll}\text { - } & \text { Pepohonan yang ditanam } \\
\text { rapat } \\
\text { - } \quad \text { perdu tahan naungan yang } \\
\text { ditanam di antara pepohonan } \\
\text { tersebut }\end{array}$ \\
\hline $\begin{array}{l}\text { Area } \\
\text { perlindungan } \\
\text { (penampung) }\end{array}$ & $\begin{array}{lr}5 \text { meter } & \text { dengan } \\
\text { daerah } & \text { buffer } \\
\text { sebesar } & 11.3 \\
\text { meter } & \end{array}$ & $\begin{array}{l}\text { Daerah bertelur } \\
\text { sebesar } 5 \text { meter } \\
\text { dan daerah } \\
\text { transisi } 11.3 \text { meter } \\
\text { - Memiliki } 30 \text { jenis } \\
\text { tanaman }\end{array}$ & $\begin{array}{l}\text { - Pepohonan yang ditanam } \\
\text { rapat } \\
\text { - Perdu tahan naungan yang } \\
\text { ditanam di antara pepohonan } \\
\text { tersebut }\end{array}$ \\
\hline Koridor & $\begin{array}{l}\text { Tak } \\
\text { (kontinyu) }\end{array}$ & & $\begin{array}{l}\text { Berupa jalur pepohonan, semak, } \\
\text { atau berupa sungai kecil }\end{array}$ \\
\hline
\end{tabular}

Sumber: The University of Montana (2010)

Berdasarkan hasil perhitungan dibutuhkan area minimum seluas 401.3 meter ${ }^{2}$ untuk keseluruhan area perlindungan penampung dengan menggunakan rumus luas lingkarang. Lot 17 kawasan SCBD tidak memenuhi kriteria luas area perlindungan sebagai sumber (source). Namun semua jenis RTH pada Lot 17 dapat dijadikan sebagai area perlindungan penampung (sink) untuk bersarang bagi satwa burung.

Suhu udara untuk burung di daerah tropis bertahan berkisar $25-30^{\circ} \mathrm{C}$. Berdasarkan data Stasiun Klimatologi Pondok Betung, suhu rata-rata sepanjang tahun 2016 adalah $27,9^{\circ} \mathrm{C}$. Kelembaban rata-rata kawasan SCBD pada tahun 2016 adalah 81,75\%. Kelembaban 
yang sesuai bagi habitat burung adalah minimum sebesar $80 \%$ dan kelembaban maksimum sebesar $84 \%$. Kenyamanan pengunjung di area taman merupakan persyaratan dasar guna menunjang aktivitas di taman (Mariski, Nasrullah, Gunawan 2017). Berdasarkan hasil perhitungan dari persamaan diatas didapatkan nilai THI sebesar 26,8 sedangkan pada daerah tropis ketidaknyamanan terjadi pada saat nilai THI lebih besar dari 27. Nilai THI hampir mencapai batas maksimal ketidaknyamanan suhu dikawasan, sehingga dibutuhkan penambahan vegetasi penaung untuk dapat menurunkan suhu.

Area penelitian ini memiliki kontur tapak cenderung datar namun terdapat lereng yang curam pada area lahan parkir. Terdapat beberapa cara untuk mencegah terjadinya longsor pada tapak dengan kemiringan curam, yakni menggunakan metode rip-rap, mulsa, tanaman, gabion, dan retaining wall.

\section{Vegetasi}

Analisis vegetasi berguna untuk mengetahui lokasi mayoritas burung untuk bersarang, makan dan tempat bereproduksi serta potensi jenis burung yang dapat dikembangkan. Selain menyediakan bagian-bagian pohon (daun, bunga, dan buah) suatu pohon dapat berfungsi sebagai habitat (atau nice habitat) berbagai jenis organisme lain yang merupakan makanan tersedia bagi burung (Setiawan et al. 2010). Vegetasi tersebut di klasifikasikan seperti pada Tabel 3.

\section{Satwa}

RTH di kawasan SCBD memiliki beberapa key pecies, seperti satwa burung, capung, kupu-kupu, dan kadal. Jenis satwa burung yang ada di kawasan SCBD diantaranya adalah punai gading (Treron vernans), tekukur biasa (Streptopelia chinensis), walet linchi (Collocalia fuchipaga), kapinis rumah (Apus affinis), caladi ulam (Dendrocopus macet), sepah kecil (Pericrocotus cinnamomeus), layang-layang batu (Hirundo tahitica), cipoh kacat (Aegithina tiphia), cucak kutilang (Pycnonotus aurigaster), merbah cerucuk (Pycnonotus goivier), gelatik batu (Parus major), remetuk laut (Gerygone sulphurea), cinenen pisang (Orthotomus sutorius), cinenen kelabu (Orthotomus ruficeps), kekep babi (Arthamus leucorhynchus), kerak kerbau (Arcridotheres javanicus), burung madu sriganti (Nectarinia jugularis), cabai jawa (Dicaeum irochileum), bondol peking (Lonchura punchulata), burung gereja (Passer montanus), dan sikep madu asia (Pernis ptilorhynchus). Burung-burung tersebut beraktifitas pada jam tertentu, yakni pukul 06.00 s.d. 08.00 WIB dan pukul 16.00 s.d. 18.00 WIB. Hasil analisis iklim menjelaskan bahwa bulan Desember adalah waktu yang sesuai untuk mengamati burung karena pada saat tersebut terjadi bulan kering yang potensial bagi burung untuk beraktivitas. Bulan November berpotensi untuk mengamati migrasi burung sikep madu asia (Pernis ptilorhynchus) (Higuchi 2016).

\section{Sosial}

Adanya burung pada tapak sudah menjadi daya tarik tersendiri bagi pengunjung dan pengelola kawasan SCBD yang ingin menjadikan RTH di SCBD ramah burung. Sebanyak $85 \%$ pengunjung yang berharap dapat berinteraksi langsung dengan burung. Berdasarkan hasil kuesioner burung yang memiliki persentase lebih dari $50 \%$ untuk dapat berinteraksi secara langsung oleh manusia adalah punai gading, tekukur, keladi ulam, kutilang, gelatik batu, burung madu sriganti, dan merpati. 
Tabel 3. Klasifikasi Vegetasi Berdasarkan Kriteria

\begin{tabular}{|c|c|c|c|c|c|}
\hline $\begin{array}{l}\text { Nama } \\
\text { Tanaman }\end{array}$ & $\begin{array}{l}\text { Jenis } \\
\text { tanaman }\end{array}$ & $\begin{array}{l}\text { Jenis makanan } \\
\text { yang dihasilkan }\end{array}$ & $\begin{array}{l}\text { Tipe } \\
\text { arsitektural }\end{array}$ & $\begin{array}{l}\text { Tinggi } \\
\text { tanaman }\end{array}$ & Jenis burung yang sesuai \\
\hline Trembesi & Pohon & Biji & Roux & Strata 5 & $1,3,4,5,6,12,16,18$ \\
\hline $\begin{array}{l}\text { Palem } \\
\text { putri }\end{array}$ & Pohon & Biji & Nezeran & Strata 3 & $8,9,26$ \\
\hline Tabebuya & Pohon & Nektar & Roux & Strata 3 & $8,9,26$ \\
\hline Beringin & Pohon & Buah & Roux & Strata 5 & $\begin{array}{l}1,2,4,5,6,8,10,11,12,18, \\
21\end{array}$ \\
\hline $\begin{array}{l}\text { Beringin } \\
\text { karet }\end{array}$ & Pohon & Buah & Roux & Strata 5 & $\begin{array}{l}1,2,4,5,6,8,10,11,12,18, \\
21\end{array}$ \\
\hline Bintaro & Pohon & Buah & Attim & Strata 3 & $\begin{array}{l}1,2,4,5,6,8,10,11,12,18, \\
21\end{array}$ \\
\hline $\begin{array}{l}\text { Pandan } \\
\text { bali }\end{array}$ & Pohon & Biji & Nezeran & Strata 3 & $8,9,26$ \\
\hline Nangka & Pohon & Buah & Rauh & Strata 3 & $\begin{array}{l}1,2,4,5,6,8,10,11,12,18, \\
21\end{array}$ \\
\hline Mangga & Pohon & $\begin{array}{l}\text { Buah } \\
\text { Penarik serangga }\end{array}$ & Rauh & Strata 4 & $\begin{array}{l}1,2,4,5,6,8,10,11,12,18, \\
21\end{array}$ \\
\hline $\begin{array}{l}\text { Asam } \\
\text { keranji }\end{array}$ & Pohon & Buah & Roux & Strata 4 & $\begin{array}{l}1,2,4,5,6,8,10,11,12,18, \\
21\end{array}$ \\
\hline $\begin{array}{l}\text { Flamboya } \\
\mathrm{n}\end{array}$ & Pohon & $\begin{array}{l}\text { Biji } \\
\text { Nektar }\end{array}$ & Roux & Strata 4 & $1,2,3,4,5,7,8,12,21,22$ \\
\hline $\begin{array}{l}\text { Glodogan } \\
\text { tiang }\end{array}$ & Pohon & $\begin{array}{l}\text { Biji } \\
\text { Buah } \\
\end{array}$ & Roux & Strata 4 & $\begin{array}{l}1,3,4,5,6,8,10,11,12,18, \\
21\end{array}$ \\
\hline Mahoni & Pohon & Biji & Roux & Strata 4 & $\begin{array}{l}1,3,4,5,6,8,10,11,12,18, \\
21\end{array}$ \\
\hline Sengon & Pohon & Penarik serangga & Nezeran & Strata 5 & $\begin{array}{l}1,2,3,4,5,6,7,9,10,11, \\
12,13,16,18,21\end{array}$ \\
\hline Palm raja & Pohon & $\begin{array}{ll}\text { Biji, } & \text { Penarik } \\
\text { serangga } & \\
\end{array}$ & Nezeran & Strata 5 & $8,9,26$ \\
\hline $\begin{array}{l}\text { Pucuk } \\
\text { merah }\end{array}$ & Pohon & Penarik serangga & Rauh & Strata 2 & $1,8,9,27,28$ \\
\hline $\begin{array}{l}\text { Hanjuang } \\
\text { merah }\end{array}$ & Semak & Biji & & Strata 1 & $8,9,26$ \\
\hline $\begin{array}{l}\text { Bambu } \\
\text { krisi }\end{array}$ & Pohon & Penarik serangga & Nezeran & Strata 3 & $1,8,9,27,28$ \\
\hline $\begin{array}{l}\text { Bambu } \\
\text { kuning }\end{array}$ & Pohon & Penarik serangga & Nezeran & Strata 3 & $1,8,9,27,28$ \\
\hline Drasaena & Semak & Penarik serangga & & Strata 1 & $1,8,9,27,28$ \\
\hline Pacing & Semak & Biji, nektar & & Strata 1 & $8,9,26$ \\
\hline $\begin{array}{l}\text { Rumput } \\
\text { gajah }\end{array}$ & $\begin{array}{l}\text { Ground } \\
\text { cover }\end{array}$ & Biji & & Strata 1 & 8 \\
\hline Soka & Semak & Nektar & & Strata 1 & 4 \\
\hline $\begin{array}{l}\text { Wali } \\
\text { songo }\end{array}$ & Semak & Penarik serangga & & Strata 1 & $1,8,9,27,28$ \\
\hline
\end{tabular}

Sumber: Analisis Penyusun, 2017

Keterangan: 1. Cucak kutilang (Pycnonotus aurigaster), 2. Bondol peking (Lonchura punctulata), 3. Bondol jawa (Lonchura leucogastroides), 4. Burung madu sriganti (Cinnyris jugularis), 5. Cipoh kacat (Aegithina tiphia), 6. Cinenen pisang (Orthotomus sutorius), 7. Cinenen jawa (Orthotomus sepium), 8. Gereja erasia (Passer montanus), 9. Tekukur biasa (Streptopelia chinensis), 10. Punai gading (Treron vernans), 11. Betet biasa (Psittacula alexandrı), 12. Cabai jawa (Dicaeum trochileum), 13. Gemak loreng ( Turnix suscitator), 14. Burung madu kelapa (Anthreptes malacensis), 15. Cekakak sungai (Halcyon chloris), 16. Pelanduk semak (Malacocincla sepiarium), 17. Wiwik kelabu (Cacomantis merulinus), 18. Kacamata biasa (Zosterops palpebrosus), 19. Remetuk laut (Gerygone sulphurea), 20. Kepudang kuduk hitam (Oriolus chinensis), 21. Sepah kecil (Pericrocotus cinnamomeus), 22. Bentet kelabu (Lanius schach), 23. Caladi tilik (Dendrocopos moluccensis), 24. Kowak malam abu (Nycticorax nycticorax), 25. Wiwik uncuing (Cacomantis sepulclaris), 26. Merpati (Columba spp.), 27. Layang-layang batu (Hirundo tahitica), 28. Gelatik batu (Parus major). 


\section{Konsep Desain Lot 17 untuk Habitat Burung}

Kosep dasar yang diterapkan pada taman ini adalah Eco-friendly bird park yang berarti taman yang mampu menghadirkan interaksi secara langsung ataupun tidak langsung antara manusia dan burung dengan menciptakan habitat yang layak bagi satwa burung sebagai daya tarik utama bagi taman itu sendiri, serta menciptakan iklim mikro yang nyaman bagi satwa burung dan manusia. Konsep desain pada taman ini menerapkan aliran seni deco merupakan murni seni dekoratif yang memiliki kesan dinamis dan bentuk plastis yang lentur (Gambar 2). Konsep deco akan dipadukan dengan pola bulu burung merak yang organik dan indah sehingga memberikan kesan dinamis. Kesan tersebut akan diterapkan dalam bentuk lengkungan pada pola-pola taman dan sirkulasi. Kesan tersebut dipadukan dengan bentukan irregular yang terkesan tidak beraturan pada bentuk ataupun susunannya untuk menghadirkan desain taman yang alami sesuai dengan preferensi pengunjung Lot 17 yang menginginkan desain tropis seperti hutan di dalam kota.

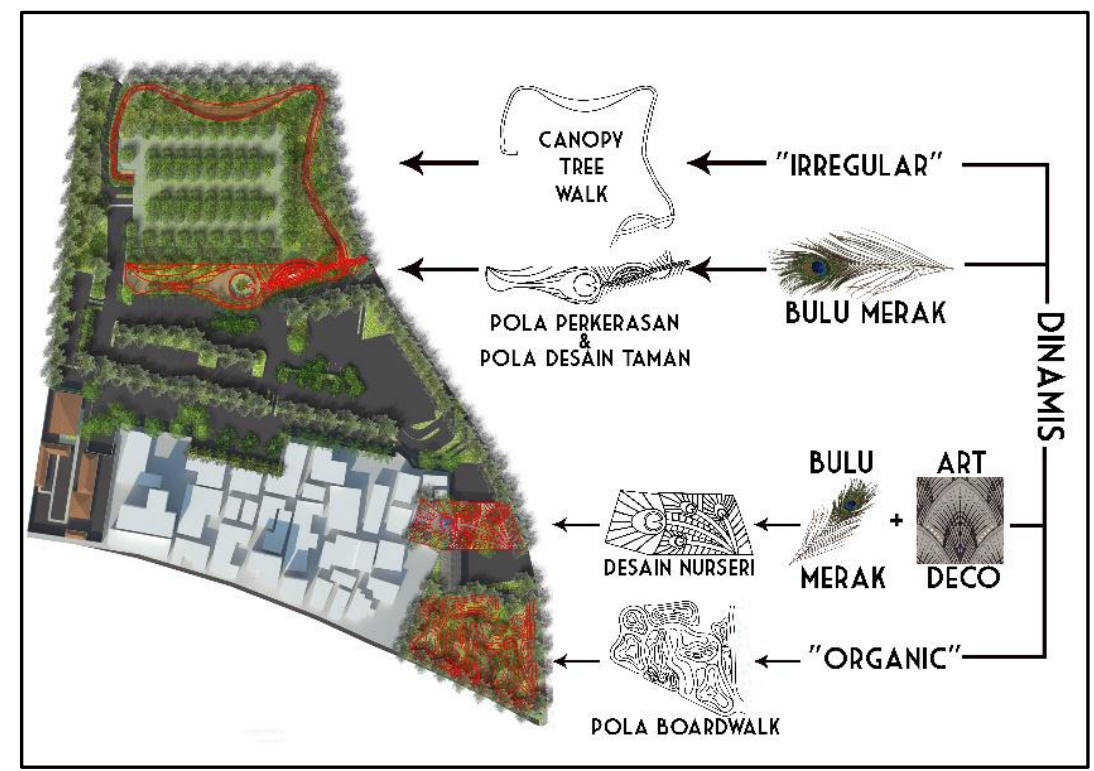

Sumber: Analisis Penyusun, 2017

Gambar 2. Konsep Desain

Konsep ruang merupakan tahapan pembagian ruang dalam tapak berdasarkan kebutuhan ruang yang ingin dihadirkan. Pembagian ruang yang sesuai dengan analisis sesuai dengan kriteria habitat burung dibagi menjadi area penampung (sink), transisi, dan koridor. Pada area penampung yang merupakan area taman itu tersendiri akan dibagi menjadi beberapa zonasi, yakni zona transisi, zona penerimaan, zona rekreasi, zona konservasi, nurseri, dan pelayanan (Tabel 4).

Konsep sirkulasi merupakan tahapan pembentukan akses antar ruang untuk memudahkan pengguna dalam menjangkaunya. Jalur interpretasi yang direncanakan akan dibuat berupa Canopy Tree Walk dengan material kayu untuk menambahkan kesan alami. Selain jalur interpretasi yang juga diperuntukkan sebagai jalur pejalan kaki, terdapat sirkulasi primer dan sekunder untuk jalur kendaraan bermotor pada area parkir.

Konsep vegetasi untuk habitat burung direncanakan memiliki fungsi-fungsi untuk bersarang, sumber pakan, bermain dan berkembang biak. Dengan demikian, jenis-jenis vegetasi yang diterapkan pada kawasan perlindungan dapat dibedakan menjadi 6 (enam) jenis vegetasi, yaitu tanaman konifer, semak, rumput, gabungan tanaman, dan tanaman peneduh. Pola desain yang diterapkan terkait konsep vegetasi pada tapak menggunakan 
pendekatan natural/alami atau penataan veegetasi dengan pola acak. Pola ini merupakan duplikasi pola alami yang terbentuk dengan sendirinya di alam liar. Fungsi dari tanaman tersebut dapat dilihat pada Tabel 5. Penggunaan tanaman semak daun dan berbungan dibutuhkan untuk menambah estetika taman. Selin itu bunga-bunga yang ada dapat menyediakan nektar sebagai makanan bagi jenis burung tertentu. Pengadaan nurseri diharapkan dapat menjadi persediaan tanaman-tanaman tersebut untuk pergiliran tanaman agar tidak monoton.

Sistem hidrologi yang dikembangkan dalam Lot 17 berupa bioswales yang kemudian akan diteruskan ke penampung dan dapat digunakan kembali untuk menyiram tanaman di taman tersebut. Penerapannya menggunakan pendekatan sistem rain garden yakni dengan memaksimalkan peresapan air hujan. Air hujan yang diserap melalui bioswale digunakan kembali untuk sistem irigasi penyiraman tanaman pada nurseri dan taman Lot 17 secara otomatis.

Tabel 4. Pembagian ruang

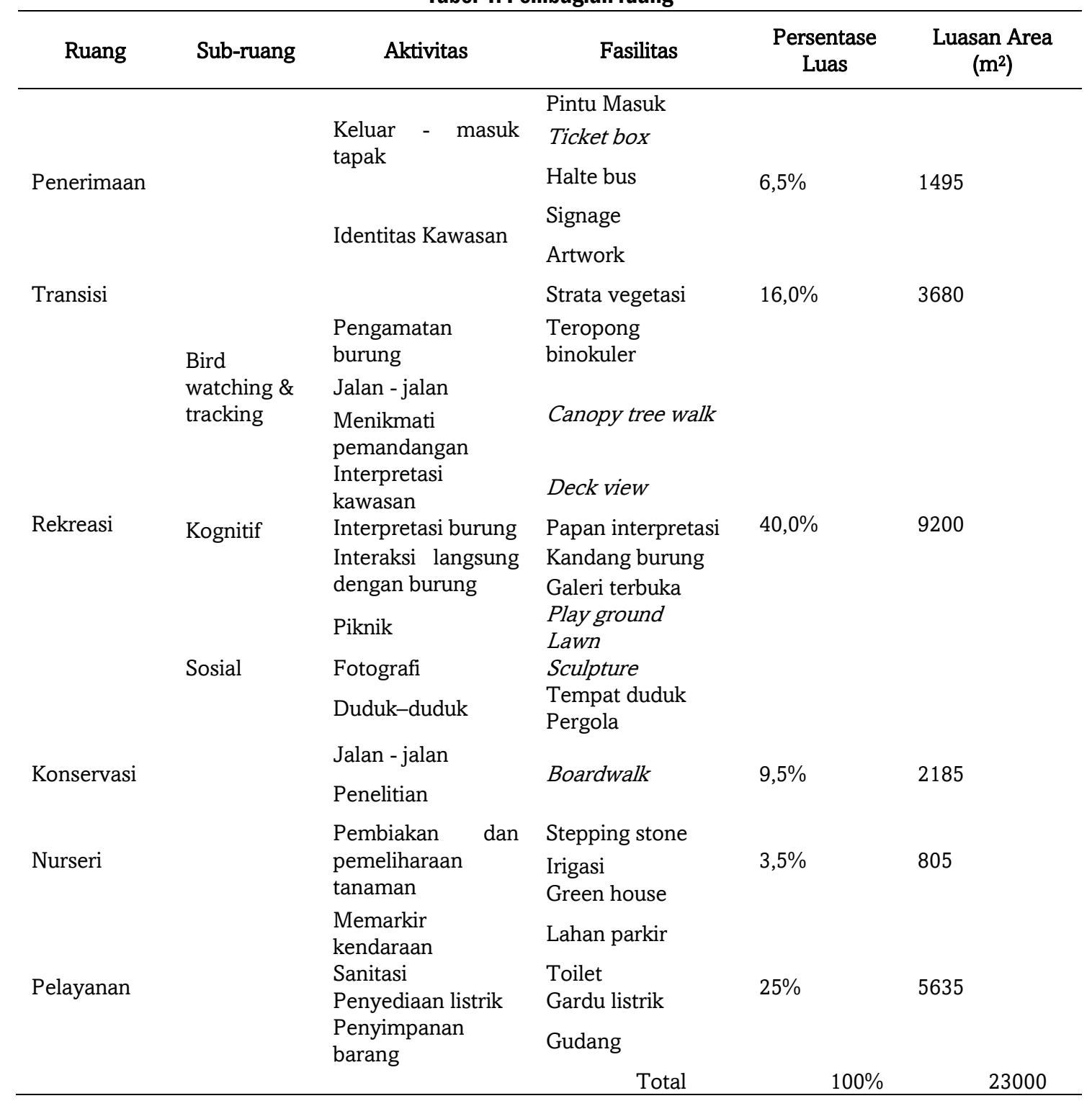

Sumber: Analisis Penyusun, 2017 
Tapak dengan luas kurang lebih 2,3 Ha didesain secara ekologis sebagai habitat burung bersarang ataupun sekedar singgah. Oleh karena itu pemilihan vegetasi pada tapak sangat penting untuk dapat mendatangkan satwa burung. Sebagai komponen habitat burung, pohon dapat berfungsi sebagai cover (tempat berlindung dari cuaca dan predator, bersarang, bermain beristirahat, dan mengasuh anak).

Tabel 5. Jenis vegetasi dan fungsinya

\begin{tabular}{lcl}
\hline \multicolumn{1}{c}{ Jenis Vegetasi } & & \multicolumn{1}{c}{ Fungsi } \\
\hline Tanaman Konifer & - & Berada di tepi daerah perlindungan \\
& - & Sebagai bahan dari area transisi \\
& - & Sebagai cadangan makanan \\
\hline Semak & - & Sebagai tempat sembunyi \\
& - & Sebagai tempat bermain \\
& - & Sebagai cadangan makanan \\
\hline Rumput & - & Sebagai tempat bermain \\
\hline Gabungan & - & Tempat bersarang dan berkembang biak \\
& - & Sumber pakan utama \\
\hline Tanaman peneduh & - & Berada di tepi daerah perlindungan \\
& - & Sebagai batas dari area transisi \\
& - & Sebagai cadangan makanan \\
\hline
\end{tabular}

Sumber: Analisis Penyusun, 2017

Berdasarkan hasil analisis vegetasi dan satwa, setelah dilakukan pemetaan vegetasi pada kawasan maka diperoleh pemetaan lokasi satwa burung pada Lot 17. Pemetaan burung didasarkan oleh jenis vegetasi yang sesuai untuk habitat burung tertentu pada suatu titik. Sehingga hal ini dapat memudahkan pengunjung untuk mengamati jenis burung yang ada pada kawasan ini berdasarkan rekomendasi lokasi yang diberikan. Peta lokasi penyebaran burung ditampilkan pada Gambar 3.

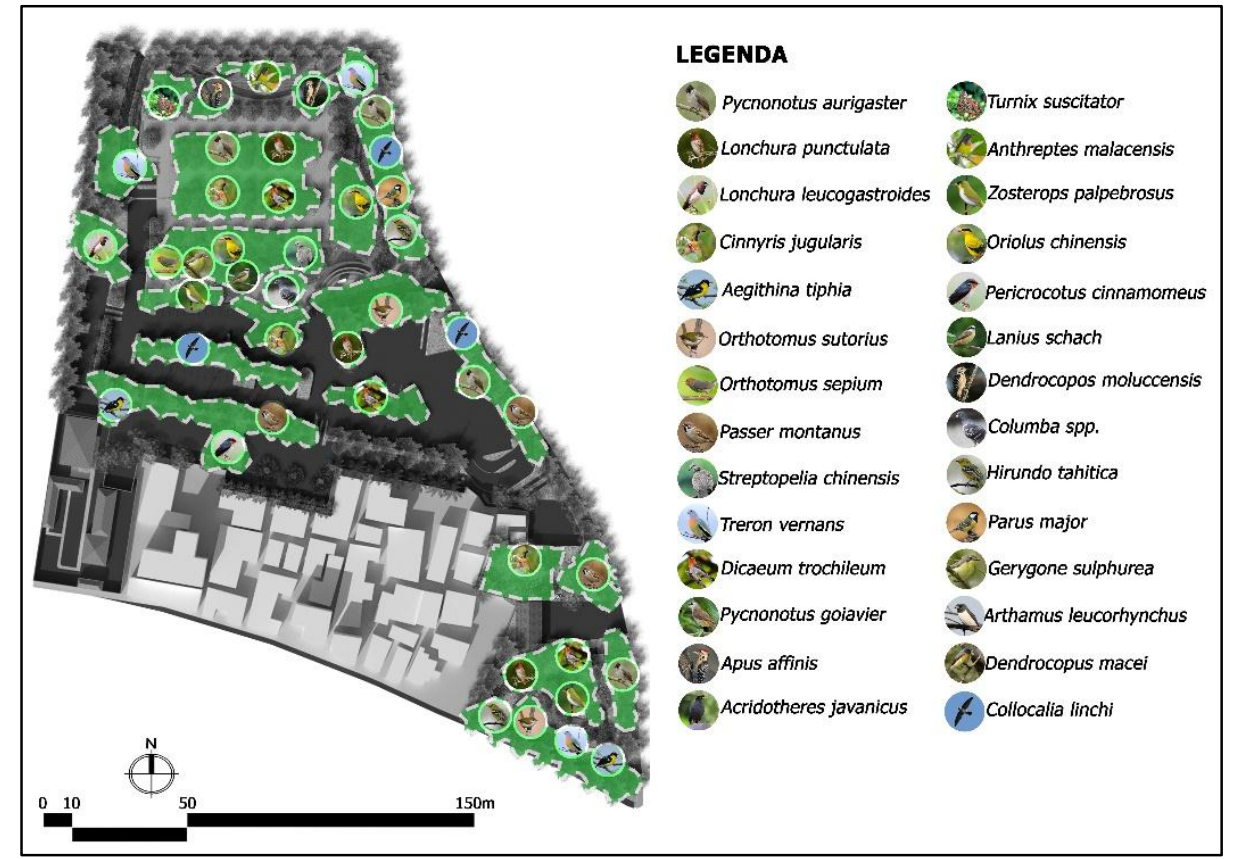

Sumber: Analisis Penyusun, 2017

Gambar 3. Desain Penyebaran Burung 
Ruang penerimaan pada Lot 17 terbagi menjadi ruang penerimaan untuk kendaraan dan ruang penerimaan untuk pejalan kaki. Terdapat 4 jalur yang membedakan antara pejalan kaki, mobil, motor, dan bus

agar mempermudah pengunjung memasuki tapak. Ruang penerimaan ini didesain menarik agar dapat menjadi perhatian pengunjung. Ruang penerimaan memiliki signage "17 PARK” dengan latar belakang berwarna biru sebagai khas warna SCBD dan memiliki sculpture berbentuk siluet burung yang terbuat dari kayu. Tidak jauh dari area penerimaan terdapat sculpture dengan bentuk burung yang besar dengan bahan material kayu rotan dan di dalamnya terdapat sculpture burung terbang yang menjadi salah satu point of interest pada kawasan ini.

Pada area konservasi, jalur pejalan kaki berupa board walk dengan lebar dua meter dan lebih tinggi $10 \mathrm{~cm}$ dari permukaan tanah (Gambar 4a). Hal tersebut dilakukan agar limpasan air hujan yang ada di dalamnya dapat mengalir dengan mudah memasukin bioswale dan langsung terserap ke dalamnya, sehingga tidak menyebabkan genangan permukaan. Kemudian pada area rekreasi jalur pejalan kaki dibedakan menjadi jalur perkerasan dan canopy tree rail (Gambar 4b). Jalur perkerasan tersebut menghubungkan area penerimaan ke area berkumpul dan children playground. Sedangkan canopy tree rail dibuat pada lahan yang miring dan terletak diantara tegakan pohon untuk memberikan sensasi berjalan di dalam hutan tropis bagi pengguna tapak.

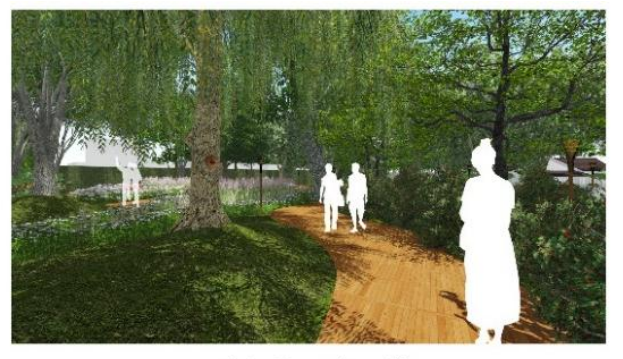

(a). Board walk

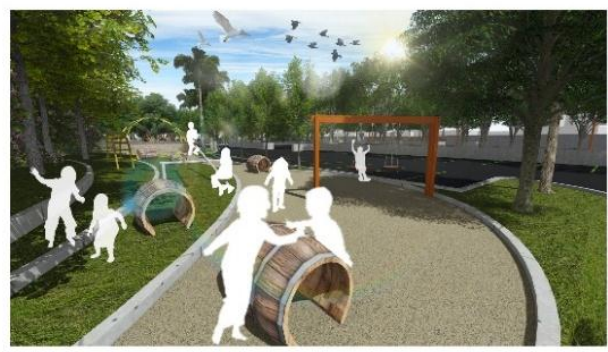

(c). Children playground

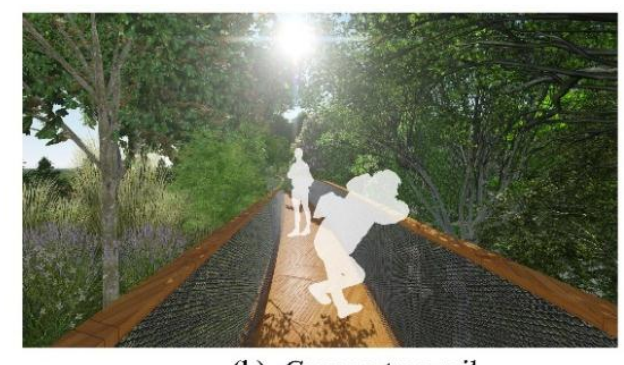

(b). Canopy tree rail

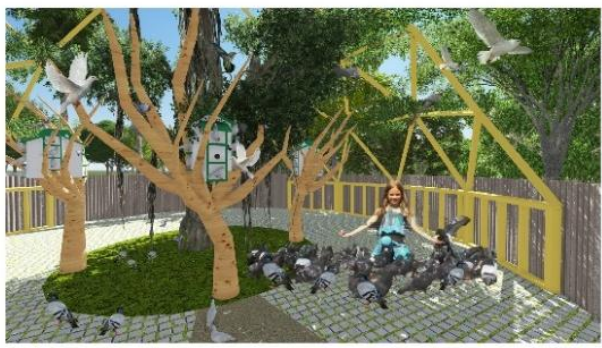

(d). Eco-bird cage

Sumber: Analisis Penyusun, 2017

Gambar 4. Perspektif

Fasilitas yang berada di perbatasan ketinggian tapak dapat digunakan oleh pengunjung tapak untuk duduk-duduk sembari melihat pemandangan dan mengamati burung. Kurangnya pemahaman pengguna tapak mengenai desain ekologis perlu ditunjang dengan papan interpretasi untuk menambah wawasan pengguna yang diisi dengan informasi mengenai penyebaran satwa burung dan penjelasan mengenai rain garden pada area konservasi. Kebutuhan pengguna tapak untuk menunjang aktivitas anak-anak agar dapat bermain diakomodasi dengan adanya playground di dalam tapak (Gambar 4c). Pada area ini, 
kondisi lahan dibuat berundak untuk memberikan variasi dan dapat digunakan sebagai amphiteater. Interaksi antara pengunjung dengan burung diakomodiasi dengan menghadirkan eco-bird cage (Gambar 4d). Sarang burung yang didesain terbuka dan dipenuhi dengan tanaman rambat agar menarik satwa liar.

Lahan parkir merupakan kondisi eksisting dari tapak yang didesain sesuai dengan menambahkan tanaman penaung agar dapat menunjang habitat bagi burung. Material yang digunakan pada lahan parkir terdiri dari dua material yakni, porous asphalt untuk area yang ada di atas dan grass block untuk area yang ada di bawah. Fasilitas lahan parkir juga menunjang pengunjung tapak yang memiliki keterbatasan (difabel) dengan menyediakan lahan parkir khusus untuk penyandang cacat. Rencana tapak keseluruhan dapat dilihat pada Gambar 5.

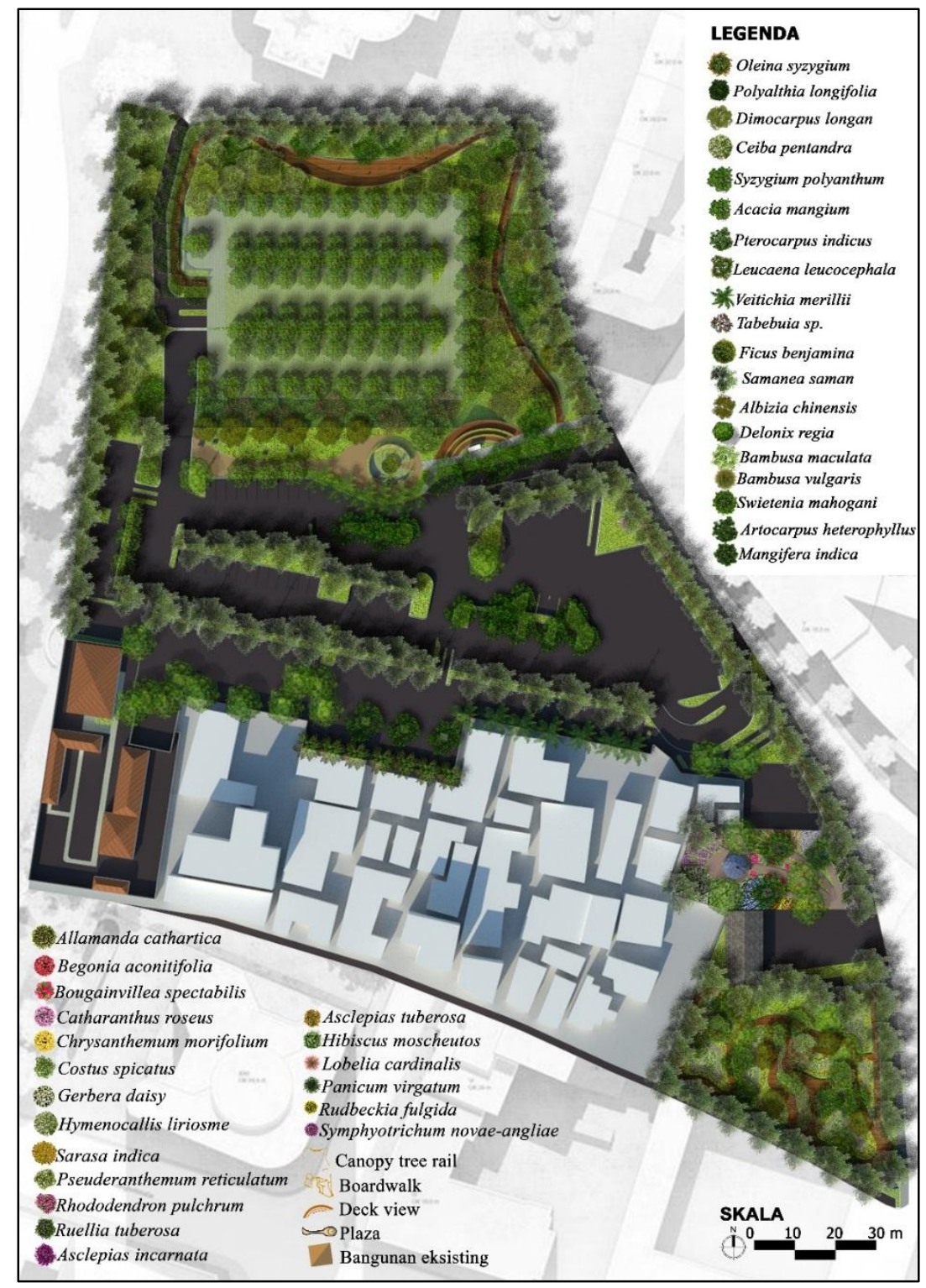

Sumber: Analisis Penyusun, 2017

Gambar 5. Rencana Tapak 


\section{KESIMPULAN}

Ruang terbuka hijau di kawasan SCBD memiliki keberagaman jenis satwa burung, diantaranya adalah punai gading ( Treron vernans), tekukur biasa (Streptopelia chinensis), walet linchi (Collocalia fuchipaga), kapinis rumah (Apus affinis), caladi ulam (Dendrocopus maceI), sepah kecil (Pericrocotus cinnamomeus), layang-layang batu (Hirundo tahitica), cipoh kacat (Aegithina tiphia), cucak kutilang (Pycnonotus aurigaster), merbah cerucuk (Pycnonotus goivier), gelatik batu (Parus major), remetuk laut (Gerygone sulphurea), cinenen pisang (Orthotomus sutorius), cinenen kelabu (Orthotomus ruficeps), kekep babi (Arthamus leucorhynchus), kerak kerbau (Arcridotheres javanicus), burung madu sriganti (Nectarinia jugularis), cabai jawa (Dicaeum irochileum), bondol peking (Lonchura punchulata), burung gereja (Passer montanus), dan sikep madu asia (Pernis ptilorhynchus). Burung-burung tersebut beraktifitas pada jam tertentu, yakni pukul 06.00 s.d. 08.00 WIB dan pukul 16.00 s.d. 18.00 WIB. Namun terdapat kendala dalam mengidentifikasi burung tersebut karena tidak setiap saat dapat diamati keberadaannya.

Ruang terbuka hijau Lot 17 SCBD berpotensi untuk dikembangkan sebagai area perlindungan penampungan (sink) burung. Tata ruang yang dapat dikembangkan secara makro adalah hubungan antara area penampung dengan area sumber dan area penampung dengan area penampung. Setiap area dihubungkan dengan koridor. Area perlindungan terbagi menjadi dua ruang yaitu area bersarang dan area transisi. Area bersarang burung difokuskan pada vegetasi yang ada sehingga area dibawah tegakan pohon dapat dimanfaatkan sebagai taman untuk manusia beraktifitas. Pemilihan jenis vegetasi ditentukan berdasarkan fungsinya yaitu untuk bersarang, bermain, atau berlindung. Namun terdapat beberapa kendala yang dimiliki oleh lokasi penelitian ini, yakni kurangnya tumbuhan semak sebagai tempat untuk bermain dan mencari makan bagi satwa burung. Sehingga ditambahkan penanaman tumbuhan semak pada Lot 17 agar dapat menarik burung turun dari kanopi dan dapat dilihat secara lebih dekat oleh manusia. Selain itu, penggunaan material yang kurang ramah lingkungan juga menjadi kendala pada tapak. Paving grass block, porous asphalt, dan boardwalk menjadi salah satu solusi mengatasi permasalahan ekologis pada tapak dan penggunaan material tersebut dapat meningkatkan porositas air serta mengurangi genangan permukaan.

Taman dengan luas 2,3 ha diwujudkan dalam enam ruang yaitu ruang penerimaan, rekreasi, konservasi, nurseri, pelayanan, dan transisi. Konsep yang diterapkan adalah "irretural d'eco", yakni penerapan konsep ekologi dengan bentukan yang irregular sehingga menciptakan kesan natural/alami. Keberadaan satwa burung pada kawasan ini juga meningkatkan nilai ekologis pada kawasan ini sekaligus kawasan perkotaan. Dengan adanya taman Lot 17 di kawasan SCBD dapat melunakkan kondisi sekitarnya yang mayoritas adalah gedung bertingkat. Pengamatan burung pada kawasan ini difasilitasi dengan teropong binokuler yang diletakkan pada deck view. Pengunjung dapat mengamati burung yang berada pada kanopi pohon melalui jalur canopy tree rail. Selain itu, pada area konservasi juga terdapat board walk yang digunakan sebagai jalur sirkulasi dan juga sebagai tempat mengamati burung.

\section{DAFTAR PUSAKA}

Aida N, Sasidhran S, Kamarudin N, Aziz N, Puan CL, Azhar B. 2016. Woody trees, green space and park size improve avian biodiversity inurban landscapes of Peninsular Malaysia. Ecological Indicators, 69:176-183.

Barth BJ, FitzGibbon SI, Wilson RS. 2014. New urban development that retain more remnant trees have greater bird diversity. Landscape and Urban Planning, 136:122-129.

Breeding Biology Research \& Monitoring Database [BBIRD] University of Montana. 2010. Kriteria luas habitat burung ideal. Montana (US). 
Booth NK. 1983. Basic Elements of Landscape Architectural Design. Illinois (US): Waveland Press.

Chong KY, Teo S, Kurukulasuriya B, Chung YF, Rajathurai S, Tan HTW. 2014. Not all green is as good: Different effects of the natural and cultivated components of urban vegetation on bird and butterfly diversity. Biological Conservation, 171:299-309.

Conole LE. Dan Kirkpatrick JB. 2011. Functional and spatial differentiation of urban bird assemblages at the landscape scale. Landscape and Urban Planning, 100:11-23.

Higuchi H. 2016. Rekam Jejak Perjalanan Migrasi Burung Menggunakan Teknologi Satellite-Tracking. Syartinilia, penerjemah; Mulyani YA, editor. Bogor (ID): IPB Press. Terjemahan dari: The Journey of Birds SatelliteTracking Bird Migration. Ed ke-1.

Mariski, Nasrullah N, Gunawan A. 2017. Persepsi dan Preferensi Pengunjung Terhadap Kenyamanan Klimatologis di Taman Menteng dan Taman Honda Tebet. Jurnal Lanskap Indonesia, 9(1):24-35.

Nieuwolt S, McGregor GR. 1998. Tropical Climatology. England (UK): John Wiley \& Sons Ltd.

Pellissier V, Cohen M, Boulay A, Clergeau P. 2012. Birds are also sensitive to landscape composition and configuration within the city centre. Landscape and Urban Planning, 104:181-188.

Pratiwi V, Gunawan A, Fatima IS. 2014. Kajian Ecodesign Lanskap Permukiman Perkotaan. Jurnal Lanskap Indonesia, 6(1):25-31.

Ramirez PC. Dan Zuria I. 2011. The value of small urban greenspaces for birds in a Mexican city. Landscape and Urban Planning, 100:213-222.

Reis E, Ibora GBL, Pinheiro RT. 2012. Changes in bird species richness through different levels of urbanization: Implications for biodiversity conservation and garden design in Central Brazil. Landscape and Urban Planning, 107:31-42.

Sandstorm UG, Angelstam P, Mikusinski G. 2006. Ecological diversity of birds in relation to the structure of urban green space. Landscape and Urban Planning, 77:39-53.

Sembiring. 2010. http:// antaranews.com. [21.59, 25 Desember 2012]

Setiawan A, Alikodra HS, Gunawan A, Darnaedi D. 2006. Keanekaragaman jenis pohon dna burung di beberapa areal Hutan Kota Bandar Lampung. Jurnal Manajemen Hutan Tropika, 12(1):1-13.

Shwartz SE. 2008. Heat capacity, time constant, and sensitivity of Earth's climate system. Journal of Geophysical Research, 113.

Strohbach MW, Lerman SB, Warren PS. 2013. Are small greening areas enhancing bird diversity? Insights from community-driven greening projects in Boston. Landscape and Urban Planning, 114:69-79.

Sulaiman S, Mohamad NHN, Idilfitri S. 2013. Contribution of Vegetation in Urban Parks as Habitat for Selective Bird Community. Social and Behavioral Science, 85:267-281.

Van der Ryn S. Dan Cowan S. 1996. Ecological Design. Washington DC: Island Press. 